\title{
Yield of irrigated cabbage submitted to different sources and doses of boron
}

\author{
Laidson Alves Leão Junior'1, Wilian Henrique Diniz Buso \\ ${ }^{1}$ Instituto Federal Goiano, Campus Ceres, Ceres, Goiás, Brasil. E-mail: lalj@outlook.com.br, wilian.buso@ifgoiano.edu.br
}

Received: 12/12/2019; Accepted: 05/07/2020.

\begin{abstract}
Cabbage is an important vegetable for food. The use of micronutrients, more specifically boron, is important for plant development and head formation. The study aimed to evaluate the agronomic performance and yield of the cabbage crop submitted to the application of different sources and doses of boron. The study was carried out in the Água Verde farm, located in Nova Glória-GO, under irrigation by a center pivot system. The soil tillage consisted of operation with a subsoiler and a disk harrow. The fertilization was carried out by applying $48 \mathrm{~kg} \mathrm{ha}^{-1}$ of N, 360 $\mathrm{kg} \mathrm{ha}^{-1}$ of $\mathrm{P}_{2} \mathrm{O}_{5}$, and $120 \mathrm{~kg} \mathrm{ha}^{-1}$ of $\mathrm{K}_{2} \mathrm{O}$, in the planting furrow. The seedling transplant took place on 06/22/2019. At 20 days after transplanting, topdressing fertilization was carried out, with $200 \mathrm{~kg} \mathrm{ha}^{-1}$ of $\mathrm{N}$ and $200 \mathrm{ha}^{-1}$ of $\mathrm{K}_{2} \mathrm{O}$. A randomized block design with four replications in a $4 \times 5$ factorial scheme was used. Four boron sources (boric acid, borax, ulexite, and Sulforgan) and five boron doses $\left(0.0,0.5,1.0,2.0\right.$, and $\left.3.0 \mathrm{~kg} \mathrm{ha}^{-1}\right)$ were evaluated. Each experimental plot consisted of four rows of five meters in length. The evaluations were carried out on the two central rows, with $0.50 \mathrm{~m}$ at each end. The variables analyzed were plant height, longitudinal diameter, transverse diameter, number of outer leaves, and yield $\left(\mathrm{kg} \mathrm{ha}^{-1}\right)$. There was no significant difference between the different boron sources evaluated. For the different boron doses applied, only the number of outer leaves did not obtain a significant regression. The application of boron at a dose of $1.8 \mathrm{~kg} \mathrm{ha}^{-1}$ resulted in the highest cabbage-head yield, totaling $82.58 \mathrm{tha}^{-1}$.
\end{abstract}

Keywords: Brassica oleracea, micronutrients, boron, yield.

\section{Produtividade do repolho irrigado submetido a diferentes fontes e doses de boro}

\section{RESUMO}

O repolho é uma hortaliça importante para a alimentação. O uso de micronutrientes, mais especificamente o boro, tem importância no desenvolvimento da planta e formação da cabeça. Objetivou-se avaliar o desempenho agronômico e produtividade da cultura do repolho submetida à aplicação de diferentes fontes e doses de boro. $\mathrm{O}$ trabalho foi conduzido na Fazenda Água Verde, situada no município de Nova Glória- GO, sob irrigação via pivô central. No preparo do solo utilizou-se uma subsolagem profunda e uma nivelagem. A adubação de base foi realizada com $48 \mathrm{~kg}$ de $\mathrm{N}, 360 \mathrm{~kg}$ de $\mathrm{P}_{2} \mathrm{O}_{5}$ e $120 \mathrm{~kg}$ de $\mathrm{K}_{2} \mathrm{O} \mathrm{ha}^{-1}$. O transplantio das mudas ocorreu no dia 22/06/2019. Aos 20 dias após o transplantio foi feita a adubação de cobertura, com $200 \mathrm{~kg} \mathrm{ha}^{-1}$ de N e $200 \mathrm{ha}^{-1} \mathrm{de}$ $\mathrm{K}_{2} \mathrm{O}$. O delineamento estatístico foi em blocos casualizados em esquema fatorial $4 \times 5$, quatro fontes de boro (ácido bórico, borax, ulexita e sulforgan) e cinco doses de boro $\left(0 ; 0,5 ; 1 ; 2 ; 3 \mathrm{~kg} \mathrm{ha}^{-1}\right)$, com quatro repetições. Cada parcela experimental foi constituída por quatro linhas de cinco metros de comprimento. Para avaliação foram consideradas as duas linhas centrais, desprezando-se $0,5 \mathrm{~m}$ em cada extremidade. As variáveis analisadas foram: altura da planta, diâmetro longitudinal, diâmetro transversal, número de folhas externas e produtividade em $\mathrm{kg}$ ha 1. Não houve diferença significativa entre as diferentes fontes de boro utilizadas. Para as diferentes doses de boro aplicadas, apenas a variável número de folhas não obteve uma regressão significativa. A aplicação de boro na dose $1,8 \mathrm{~kg} \mathrm{ha}^{-1}$ propiciou a máxima produção de cabeças de repolho, totalizando uma produtividade de 82,58 ton $\mathrm{ha}^{-1}$.

Palavras-chave: Brassica oleracea, micronutriente, boro, produtividade. 


\section{Introduction}

Belonging to the Brassicaceae family, cabbage (Brassica oleracea var. Capitata), is an herbaceous vegetable, with rounded and waxy leaves, which form a compact head, and has a biennial cycle (Moreira et al., 2011). With a constant presence on the Brazilian table, it is a food of great importance in the human diet due to its high nutritional value, especially for the content of calcium and vitamins C, B1, B2, mineral salts, besides being a very versatile food in the industry and on the table, and can be eaten fresh, cooked or dehydrated (Filgueira, 2012). Cabbage is among the three most consumed vegetables in the Brazilian market, due to the high rate of growth and yield, being a constant target of research (Perin et al., 2015).

According to Luz et al., (2002) the Brazilian hybrid, Astrus, produces globular heads weighing between 1.5 and $2.0 \mathrm{~kg}$, has dark green leaves a cycle ranging fron 80 to 90 days, it still presents resistance to cracking, Fusarium wilt and black rot (Xanthomonas campestre), besides being heat tolerant. However, over time, cultivars adapted to high temperatures were obtained, consequently extending the planting and harvest periods (Filgueira, 2013).

Cabbage originates from the Northern Coast of the Mediterranean, Asia Minor, and Western Coast of Europe Coast (Ruiz Junior et al., 2012), which are regions of temperate climate. The largest world producers are China, India and Russia and Russia is the largest workd consumer (FAOSTAT, 2017). In 2018, Brazil produced approximately 417.489 thousand tons of cabbage (IBGE, 2017). Reis et al. (2017) explain that in Brazil, cabbage crop stands out economically due to the high volume of production and consumption.

According to Cassol et al., (2017), the production of cabbage gains prominence in the socioeconomic aspect, since most of the production is carried out by family farming, requiring intensive labor in small cultivation areas, and the vegetables are considered highly profitable. In this sense, Silva et al. (2012) report that the estimate is for each hectare planted with vegetables, between 3 and 6 direct jobs, and an equal number of indirect jobs will be generated.

According to Malavolta (2006) the chemical element boron (B) is immobile in the phloem and does not redistribute itself in the plant; thus, the nutritional deficiency of this micronutrient is verified in younger organs. Fertilization with micronutrients is essential, as it promotes an increase in the crop yield potential so that the low concentration of micronutrients limits yield. According to Silva et al. (2012) maximum yield was obtained with the application of $7.2 \mathrm{~kg} \mathrm{ha}^{-1}$ of boron.

The group of species from the Brassicaceae family is one of the most demanding in boron, and its deficiency can cause the appearance of dark color in the central part of the stem (Malavolta et al., 1997). The authors also state that in Brazilian soils, boron, and zinc $(\mathrm{Zn})$ are the micronutrients found in the lowest quantity. Therefore, boron fertilization for Brassicaceae plants in Brazil is frequently recommended, considering that the few results indicate a positive response to the use of this micronutrient (Bergamin et al., 2005). However, there is a lack of information on the use of this micronutrient in the cultivation of cabbage. Given the above, the study aimed to evaluate the influence of boron on yield and agronomic traits of cabbage submitted to different sources and doses of boron.

\section{Material and Methods}

The study was carried out in field conditions, in the Água Verde farm, located in Nova Glória-GO, (235' $88^{\prime \prime} \mathrm{S}, 34^{\circ} 45^{\prime} 07^{\prime \prime} \mathrm{W}$, and altitude of $623 \mathrm{~m}$ ) under irrigation by a center pivot system. The climate of the region is Aw-type, according to the Köppen classification, defined as humid tropical, with a rainy season in summer and a dry season in winter. According to data from the National Institute of Meteorology (Figure 1), the maximum temperature during the experiment was $32^{\circ} \mathrm{C}$ (INMET, 2019).

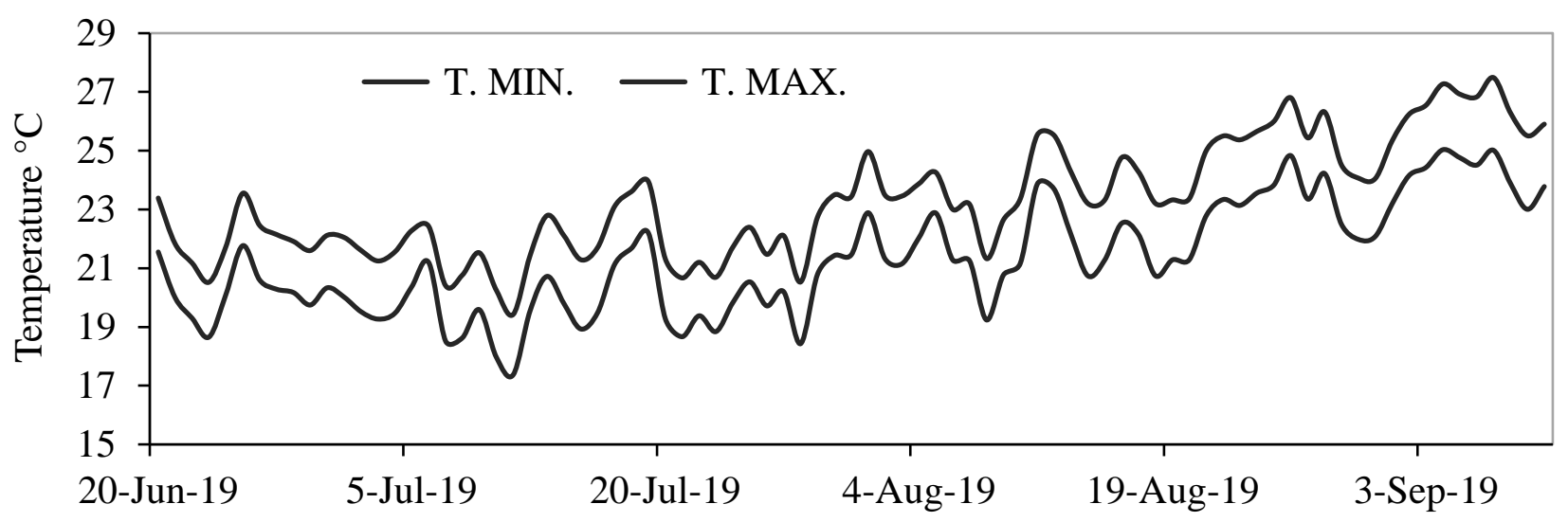

Figure 1. Maximum and minimum temperature during the experiment. 
For fertility assessment purposes, soil samples were collected in the 0-20 cm layer for chemical analysis; the results are shown in Table 1 . The soil is classified as a Oxisol.

The soil tillage consisted of operation with a subsoiler and three operations with a disk harrow, the last one being the day before the installation of the experiment. The fertilization was carried out by applying $48 \mathrm{~kg} \mathrm{ha}^{-1}$ of $\mathrm{N}, 360 \mathrm{~kg} \mathrm{ha}^{-1}$ of $\mathrm{P}_{2} \mathrm{O}_{5}$, and $120 \mathrm{~kg} \mathrm{ha}^{-1}$ of $\mathrm{K}_{2} \mathrm{O}$, in the planting furrow. The cabbage seedlings were produced in the Emilio Mudas commercial nursery, using the Astrus cabbage hybrid. The seeds were sown in 200-cell trays (05/22/2019), using the commercial substrate Bioplant ${ }^{\circledR}$. Germination and seedling development occurred in a greenhouse with a micro-sprinkler irrigation system.

The transplanting of the seedlings was carried out 30 days after sowing (DAS), on 06/22/2019, manually. The spacings of $0.5 \mathrm{~m}$ and $0.3 \mathrm{~m}$ between rows and between plants were used, respectively. The spacing between rows was determined according to the row spacing of the equipment used to carry out the fertilization. The seedling transplanting was carried out manually. Boron was distributed on the planting row, one day after the seedling transplanting. At 20 days after transplanting, the topdressing fertilization was carried out, applying $200 \mathrm{~kg}$ $\mathrm{ha}^{-1}$ of $\mathrm{N}$ and $200 \mathrm{ha}^{-1}$ of $\mathrm{K}_{2} \mathrm{O}$.

The herbicide S-metolachlor was applied the day after transplanting $\left(1 \mathrm{~L} \mathrm{ha}^{-1}\right)$ for the weed control. The control of insects and diseases followed the technical recommendations for the cabbage cultivation. The irrigation management was carried out with the aid of a Class-A evaporation pan, and the irrigation depth applied was corrected by the crop coefficient $(\mathrm{Kc})$ of cabbage, according to its phenological stages, according to Marouelli et al., (2017).
A randomized block design with four replications in a 4x5 factorial scheme was used. Four boron sources (boric acid, borax, ulexite, and Sulforgan) and five boron doses $\left(0.0,0.5,1.0,2.0\right.$, and $\left.3.0 \mathrm{~kg} \mathrm{ha}^{-1}\right)$ were evaluated.

Each experimental plot consisted of four rows of five meters spaced $0.50 \mathrm{~m}$ apart. The evaluations were carried out on the two central rows, with $0.50 \mathrm{~m}$ at each end. In the harvest carried out on $09 / 08 / 2019$, four plants from the central rows were collected to determine the yield components, plant height, longitudinal and transverse diameter (measured with the aid of a tape measure), number of outer leaves (by counting the fully open leaves), and yield in $\mathrm{kg} \mathrm{ha}^{-1}$ (determined by weighing the heads harvested in the useful area of the plot and corrected for the commercial area.

All data were subjected to analysis of variance and the F-test. The Tukey test compared the means from the boron sources at $5 \%$ probability. The means from the boron doses were submitted to regression analysis. The analyses were performed with the aid of R software.

\section{Results and Discussion}

The boron content in the soil before the seedling

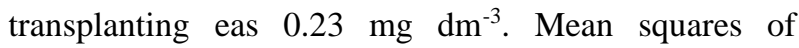
ANOVA, as well as the significance of the regression for the quantitative factor (boron doses), are shown in Table 2. It is observed that there was no significant interaction for any of the variables evaluated; thus, the analyzes were performed individually. According to the regression analyses, the variables that best adjust the linear model were plant height (PH), longitudinal diameter (LD), and transverse diameter (TD); the yield (YLD) was adjusted to the quadratic model. There was no adjustment to the regression models for the number of outer leaves, as shown in Table 2.

Table 1. Soil chemical properties in the $0-0.20 \mathrm{~cm}$ layer, Ceres, GO, 2019.

\begin{tabular}{|c|c|c|c|c|c|c|c|c|}
\hline Sand & Silt & Clay & \multirow{2}{*}{$\mathrm{pH}\left(\mathrm{CaCl}_{2}\right)$} & \multirow{2}{*}{$\begin{array}{l}\text { O.M. } \\
\mathrm{g} \mathrm{dm}^{-3}\end{array}$} & & & $\mathrm{Mg}$ & $\mathrm{Al}$ \\
\hline & $\mathrm{g} \mathrm{kg}^{-1}$ & & & & \multicolumn{4}{|c|}{$\mathrm{cmol} \mathrm{dm}^{-3}$} \\
\hline \multirow[t]{4}{*}{390} & 110 & 500 & 4.8 & 19 & & & 0.6 & 0.1 \\
\hline & $\mathrm{H}+\mathrm{Al}$ & $\mathrm{K}$ & $\mathrm{CEC}^{*}$ & $\mathrm{~K}$ & $\mathrm{P}$ & $\mathrm{B}$ & \multirow{2}{*}{\multicolumn{2}{|c|}{ V }} \\
\hline & \multicolumn{3}{|c|}{$\mathrm{cmol} \mathrm{dm}^{-3}$} & \multicolumn{3}{|c|}{$\mathrm{mg} \mathrm{dm}^{-3}$} & & \\
\hline & 4.0 & 0.30 & 6.73 & 116.6 & 67.0 & 0.23 & & \\
\hline
\end{tabular}

Source: Solocria Laboratório Agropecuário Ltda. 2019. *CEC = Cation Exchange Capacity.

Table 2. Mean squared error of the sources (S), doses (D), and sources $x$ doses interaction (S x D), for the variables plant height (PH), number of outer leaves (NL), longitudinal diameter (LD), transverse diameter (TD), and yield (YLD) of cabbage grown with doses and sources of boron.

\begin{tabular}{|c|c|c|c|c|c|}
\hline \multirow{2}{*}{ Variables } & \multicolumn{3}{|c|}{ Mean squared error ${ }^{1}$} & \multicolumn{2}{|c|}{ Regression } \\
\hline & $\mathrm{S}$ & $\mathrm{D}$ & S x D & Linear & Quadratic \\
\hline $\mathrm{PH}$ & $0.0006^{\mathrm{ns}}$ & $0.0037^{*}$ & $0.0009^{\mathrm{ns}}$ & $0.0090416^{*}$ & $0.0000324 \mathrm{~ns}$ \\
\hline NL & $1.9814^{\mathrm{ns}}$ & $1.9814^{\text {ns }}$ & $1.0976^{\mathrm{ns}}$ & 6.3547 ns & 3.9663 ns \\
\hline LD & $0.0851^{\mathrm{ns}}$ & $1287.9861^{*}$ & $46.6435^{\mathrm{ns}}$ & $3472.5 *$ & $712.8^{\mathrm{ns}}$ \\
\hline TD & $1066.20^{\mathrm{ns}}$ & $4330.8278^{*}$ & $363.9481 \mathrm{~ns}$ & $6778.1 *$ & $2063.6^{\mathrm{ns}}$ \\
\hline YLD & $362.8093^{\mathrm{ns}}$ & $3183.8305^{*}$ & $292.0919 \mathrm{~ns}$ & $4081.1^{\mathrm{ns}}$ & $5364.7 *$ \\
\hline
\end{tabular}

1* Significant by the F-test $(\mathrm{p}=0.05) ; \mathrm{ns}=$ not significant; $\mathrm{S}=$ Boron sources; $\mathrm{D}=$ Boron doses; $\mathrm{S} \times \mathrm{D}=$ interaction between sources and doses of boron. 
From the results obtained, there was no statistical difference between the different sources of boron in the cabbage crop (Table 3). About boron doses, a significant effect was observed on plant height, longitudinal diameter, transverse diameter, and yield, the significance of which is shown in Table 2, and the means are shown in Table 3.

There was no influence of boron sources on the number of outer leaves (Table 3). For the doses, the regression analysis was not significant (Table 2), and the averages ranged between 8.66 and 9.74 leaves per plant.

There was no influence of the application of boron doses on the plant height, according to the averages shown in Table 3. Silva et al. (2014) using doses of boron $\left(0 ; 2.5 ; 5.0 ; 7.5\right.$ and $\left.10.0 \mathrm{~kg} \mathrm{ha}^{-1}\right)$ with boric acid as the source did not observe any difference for plant height, and the average was $30.40 \mathrm{~cm}$, close to the values obtained in the present study, whose average was 37.70 $\mathrm{cm}$. Born supplied via soil is best used by the plant, as it is through the root the primary way of absorption of the nutrient, as well as its mobility to the plant tissues (Taiz and Zeiger, 2013). Thus, it is justified that there is no difference between the sources since the availability of boron met the demand for growth regardless of the source used.

When the boron doses were evaluated, adjustment to the linear model was observed (Figure 2). Thus, the increase in the availability of boron in the soil promoted higher plant growth, as boron acts in the cementation of the wall and cell elongarion and still maintains the integrity of the cell membrane, besides acting in the meristematic reions of plant growth during the vegetative and reproductive development (Taiz and Zeiger, 2013). Also, with the highest dosage of boron, the highest height of cabbage plants was obtained.

For the longitudinal (DL) and transverse (DT) diameter of the head, adjustment of the data to the linear model was observed, as shown in Figures 3 and 4. Boron facilitates the transport of carbohydrates (Taiz and Zeiger, 2013), which can facilitate the appearance of leaves for head formation. Silva et al. (2012) found a linear increase in the diameter of the head according to boron doses, a result similar to that obtained in this study. Pizetta et al. (2005) evaluating boron doses $(0 ; 2 ; 4 ; 6$ and $8 \mathrm{~kg} \mathrm{ha}^{-1}$ ) also found a linear increase in the diameter of the head according to the doses, obtaining a $6 \%$ increase in the diameter of the head with the dose $8 \mathrm{~kg} \mathrm{ha}^{-1}$. The longitudinal diameter ranged from $119.37 \mathrm{~mm}\left(0.0 \mathrm{~kg} \mathrm{ha}^{-1}\right)$ to $143.12 \mathrm{~mm}\left(3.0 \mathrm{~kg} \mathrm{ha}^{-1}\right)$, which corresponds to an increase of $23.75 \mathrm{~mm}$. For the transverse diameter, there as an increase of $41.06 \mathrm{~mm}$ from the smallest to the highest dose of boron used.

When the yield was evaluated according to the boron doses (Figure 5), it was observed that the data adjusted to the quadratic regression model, whose dose that provided the highest productivity was $1.8 \mathrm{~kg} \mathrm{ha}^{-1}$ of boron, which reached $82.58 \mathrm{t} \mathrm{ha}^{-1}$. The formation of heads with larger diameters (Figures 3 and 4) may have contributed to increases in yield. These results are similar to those found by Silva et al. (2012), who analyzed the yield and the development of cabbage cultivars as a function of boron doses $(0 ; 2.5 ; 5.0 ; 7.5$; $10 \mathrm{~kg} \mathrm{ha}^{-1}$ of boron), they observed data adjustment to a quadratic regression model, with a maximum point obtained with $7.2 \mathrm{~kg} \mathrm{ha}^{-1}$ of boron.

The cabbage yields obtained in this experiment are above the range mentioned by Trani et al. (1996), between 30 to $60 \mathrm{t} \mathrm{ha}^{-1}$. This difference in productivity is due in part to more productive cultivars developed in recent years, in addition to improvements in fertilization and plant nutrition adopted by producers. Pizetta et al. (2005), in studies with broccoli, cabbage, and cauliflower, obtained positive responses with the increase of boron doses in the crops, thus demonstrating the strong relationship between the boron application and the increase in yield of Brassicaceae plants.

Table 3. Plant height (PH), number of outer leaves (NL), longitudinal diameter (LD), transverse diameter (TD) and yield of cabbage grown with doses and sources of boron, 2019.

\begin{tabular}{|c|c|c|c|c|c|}
\hline Sources & $\mathrm{PH}$ & $\mathrm{NL}$ & LD & TD & Yield \\
\hline Boric acid & $0.38 \mathrm{a}$ & $9.42 \mathrm{a}$ & $135.33 \mathrm{a}$ & $133.16 \mathrm{a}$ & $64.24 \mathrm{a}$ \\
\hline Ulexite & $0.38 \mathrm{a}$ & $8.93 \mathrm{a}$ & $135.25 \mathrm{a}$ & $149.08 \mathrm{a}$ & $74.30 \mathrm{a}$ \\
\hline Sulforgan & $0.38 \mathrm{a}$ & $9.66 \mathrm{a}$ & $133.41 \mathrm{a}$ & $136.40 \mathrm{a}$ & $67.38 \mathrm{a}$ \\
\hline Borax & $0.37 \mathrm{a}$ & $9.45 \mathrm{a}$ & $134.16 \mathrm{a}$ & $144.50 \mathrm{a}$ & $70.02 \mathrm{a}$ \\
\hline Doses & $\mathrm{PH}$ & $\mathrm{NL}$ & LD & TD & Yield \\
\hline 0.0 & 0.35 & 8.66 & 119.37 & 112.89 & 43.89 \\
\hline 0.5 & 0.38 & 9.41 & 135.83 & 151.87 & 76.43 \\
\hline 1.0 & 0.36 & 9.45 & 136.04 & 143.54 & 74.13 \\
\hline 2.0 & 0.38 & 9.74 & 138.33 & 141.66 & 76.95 \\
\hline 3.0 & 0.39 & 9.60 & 143.12 & 153.95 & 73.55 \\
\hline $\mathrm{CV} \%$ & 9.17 & 14.86 & 10.47 & 18.57 & 19.27 \\
\hline
\end{tabular}

Means followed by the same letters in the columns are statistically equal by the Tukey test at $5 \%$ probability. 


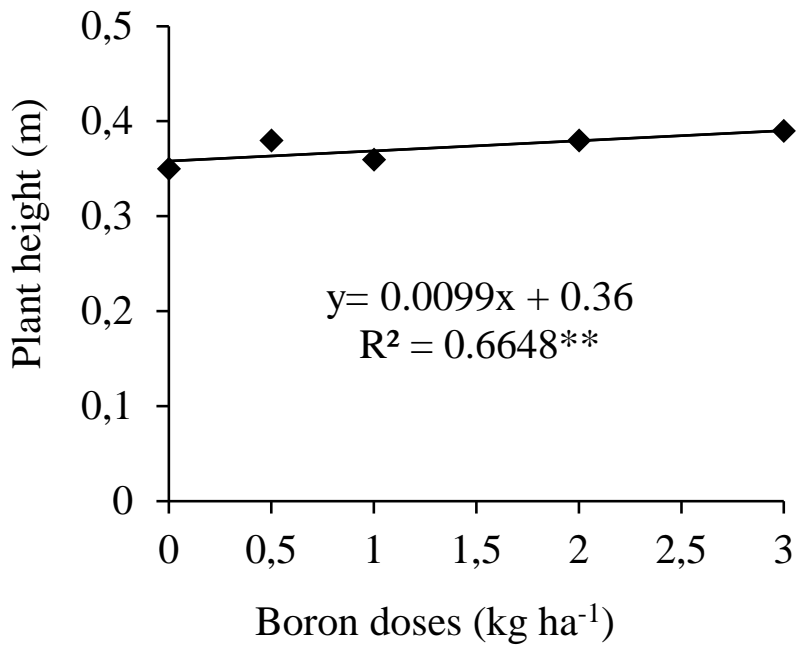

Figure 2. Plant height of cabbage according to the boron doses.

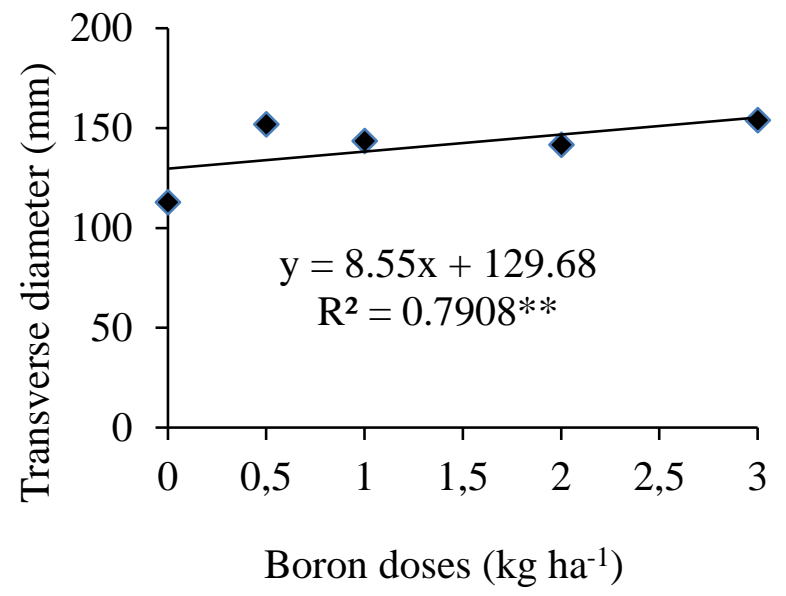

Figure 4. Transverse diameter of cabbage-head according to the boron doses.

Adequate boron supply is essential to obtain yield gain besides contributing to plant health, as this element increases the integrity of plasmalemma, reducing losses of free amino acids that could serve as food for pests. Also, adequate levels of boron in the plant increase the excretion of sugars in the soil, which can facilitate the mycorrhization process and contribute to the plant's nutrition (Malavolta, 2006).

\section{Conclusions}

Under the conditions that this experiment was conducted, the boron application at a dose of $1.8 \mathrm{~kg} \mathrm{ha}^{-1}$ resulted in the highest cabbage-head yield, totaling 82.58 $\mathrm{t} \mathrm{ha}^{-1}$.

More research needs to be carried out with boron in Brassicaceae plants to determine the best dose to favor the development and yield.

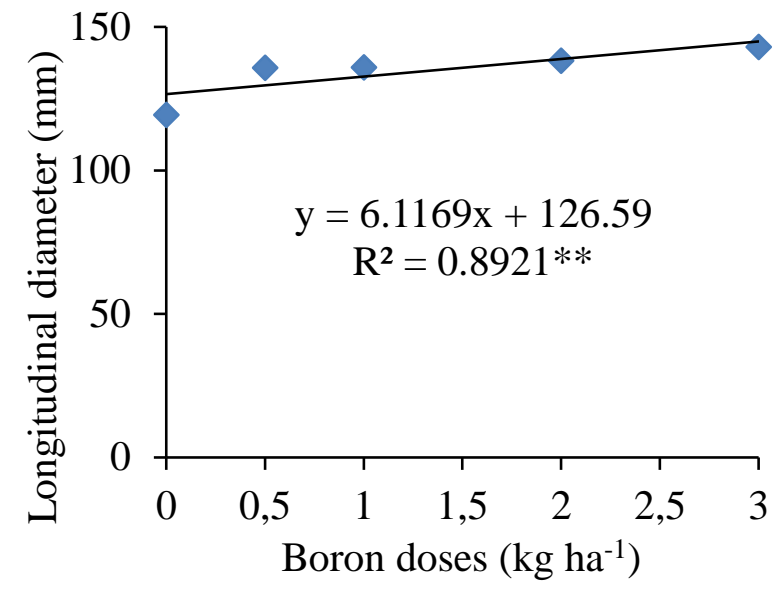

Figure 3. Longitudinal diameter of cabbage-head according to the boron doses.

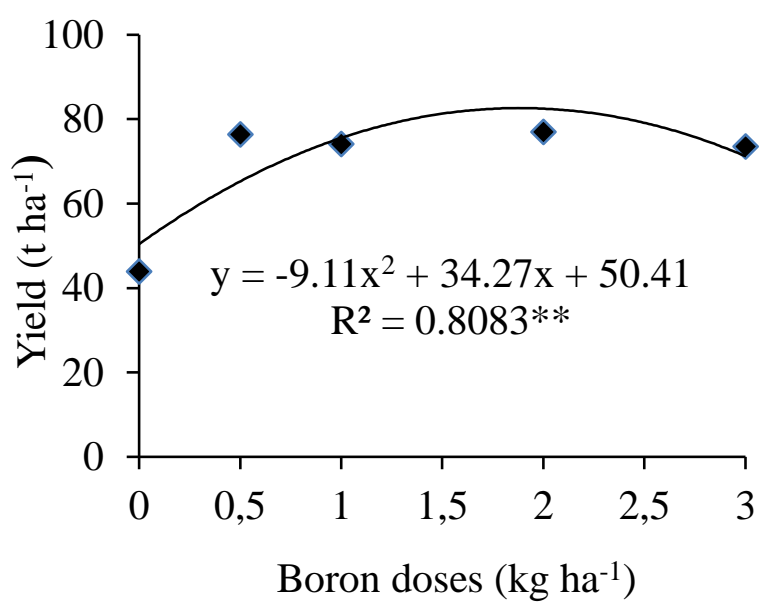

Figure 5. Yield of cabbage according to the boron doses.

\section{Bibliographic References}

Bergamin, L.G., Cruz, M.C.P., Ferreira, M.E., Barbosa, J.C., 2005. Produção de repolho em função da aplicação de boro associada à adubo orgânico. Horticultura Brasileira, 23(2), 311315.

Cassol, S.P., Lenhardt, E.R., Gabriel, V.J., 2017. Caracterização dos estádios fenológicos e a exigência de adubação do repolho. Ciências agroveterinárias e alimentos, 2 , $1-12$.

FAOSTAT, 2017. Countries by commodity. http://www.fao.org/faostat/en/\#rankings/countries_by_commo dity (acessado 19 de setembro de 2019).

Filgueira, F.A.R., 2012. Novo manual de olericultura: agrotecnologia moderna na produção e comercialização de hortaliças, terceira ed. Viçosa, UFV.

Filgueira, F.A.R., 2013. Novo manual de olericultura: agrotecnologia moderna na produção e comercialização de hortaliças, terceira ed. rev. ampl. Viçosa, UFV. 
IBGE, 2017. Horticultura (Número de estabelecimentos agropecuários e Quantidade produzida, por produtos da horticultura. 2017). https://sidra.ibge.gov.br/tabela/6619 (acessado 10 de julho de 2019).

INMET. Instituto Nacional de Meteorologia, 2019. http://www.inmet.gov.br/portal/index.php?r=home/page\&page =rede_estacoes_auto_graf (acessado 02 de dezembro de 2019).

Luz, F.J.F., Saboya, R.C.C., Pereira, P.R.V.S., 2002. O cultivo do repolho em Roraima. Boa Vista, Embrapa Roraima, 17 p. (Circular técnica, 7).

Malavolta, E., 2006. Manual de nutrição mineral de plantas. São Paulo, Agronômica Ceres.

Malavolta, E., Vitti, C.G., Oliveira, S.A., 1997. Avaliação do estudo nutricional das plantas: princípios e aplicações. Piracicaba, Potafós.

Marouelli, A.W., Melo, R.A.C., Braga, M.B., 2017. Irrigação no cultivo de brássicas. Embrapa Hortaliças, Brasília, 25 p. (Circular técnica, 158).

Moreira, M.A., Vidigal, S.M., Sediyama, M.A.N., Santos, M.R., 2011. Crescimento e produção de repolho em função de doses de nitrogênio. Horticultura Brasileira, 29(1), 117-121.

Perin, A., Cruvinel, D.A., Ferreira, H.S., Melo, G.B., Lima, L.E., Andrade, J.W.S., 2015. Decomposição da Palhada e Produção de Repolho em Sistema Plantio Direto. Global Science and Technology, 8(2), 153-159.
Pizetta, L.C., Ferreira, M.E., Cruz, M.C.P., Barbosa, J.C., 2005. Resposta de brócolis, couve-flor e repolho à adubação com boro em solo arenoso. Horticultura Brasileira, 23(1), 51-56.

Reis, M.R., Melo, C.A.D., Raposo, T.P., Aquino, R.F.B.A., Aaquino, L.A., 2017. Selectivity of herbicides to cabbage (Brassica oleracea var. capitata). Planta Daninha, 35(1), 1-6.

Ruiz Junior, E.C., Gonçalves, F.M., Michelan, K.S., Hora, R.C., 2012. Avaliação fitotécnica de plantas de repolho roxo cultivadas sob diferentes densidades e fontes de nitrogênio. Cultivando o saber, 5(4), 124-132.

Silva, K.S., Santos, E.C.M., Benett, C.G.S., Laranjeira, L.T., Eberhardt Neto, E., Costa, E., 2012. Produtividade e desenvolvimento de cultivares de repolho em função de doses de boro. Horticultura Brasileira, 30(3) 520-525.

Silva, L.M., Basílio, S.A., Silva Júnior, R.L., Nascimento, M.V., Benett, C.G.S., Benett, K.S.S., 2014. Aplicação de ácido bórico sobre as características produtivas do repolho em diferentes épocas. Revista de Agricultura Neotropical, 1(2), 2634 .

Taiz, L., Zeiger, E., 2013. Fisiologia vegetal, quinta ed. Porto Alegre, Artemed.

Trani, P.E., Passos, F.A., Azevedo, J.A., Tavares, M., 1996. Brócolos, couve-flor e repolho, in: Raij, B.V., Cantarella, H., Quaggio, J.A., Furlani, A.M.C., (Ed.). Recomendações de adubação e calagem para o Estado de São Paulo. Campinas-SP: Instituto Agronômico/Fundação IAC, 285 p. (Boletim técnico, 100). 